\title{
Alcohol consumption and the risk of Internet addiction in teenagers aged 13-17 years living in the urban and rural areas
}

\author{
Spożywanie alkoholu a zagrożenie uzależnieniem od Internetu u młodzieży \\ w wieku od 13 do 17 roku życia mieszkającej w mieście i na wsi
}

\author{
Maciej Zygo ${ }^{1}{ }_{\mathrm{B}, \mathrm{E}, \mathrm{F}, \mathrm{G}}$, Emilia Potembska ${ }^{2} \mathrm{~A}, \mathrm{C}, \mathrm{D}, \mathrm{E}, \mathrm{F}, \mathrm{G}$, Karol Zygo ${ }^{3}{ }_{\mathrm{B}, \mathrm{E}}$, \\ Andrzej Stanisławek ${ }^{4} \mathrm{E}, \mathrm{F}$, tukasz Karaś ${ }_{\mathrm{E}, \mathrm{F}}$, Beata Pawłowska ${ }_{\mathrm{A}, \mathrm{C}, \mathrm{D}, \mathrm{E}, \mathrm{F}, \mathrm{G}}$
}
${ }^{1}$ Prof. Mieczysław Kaczyński Neuropsychiatric Hospital in Lublin Independent Public Healthcare Establish- ment, Poland
${ }^{2}$ Department of Psychiatric Nursing, Medical University in Lublin, Poland
${ }^{3}$ Department of Ethics and Human Philosophy, Medical University in Lublin, Poland
${ }^{4}$ Department of Oncology, Medical University in Lublin, Poland
${ }^{5}$ Department of Trauma and Orthopaedic Surgery SP ZOZ Hospital in Łęczna, Poland
${ }^{6}$ 2nd Department of Psychiatry and Psychiatric Rehabilitation, Medical University in Lublin, Poland

\begin{abstract}
The aim of this paper was to determine differences and similarities between city dwelling teenagers aged 13-17 years who consumed/did not consume alcohol and their rural counterparts in regard to the severity of Internet addiction symptoms.

Participants and methods: The examined group consisted of 1,191 people (890 girls and 301 boys) aged $13-17$ years. The following instruments were used in the study: a sociodemographic questionnaire designed by the present authors, the Internet Addiction Questionnaire designed by Potembska, and the Internet Addiction Questionnaire (KBUI) designed by Pawłowska and Potembska.

Results: The results show that adolescents who consume alcohol, both those living in urban and rural areas, are characterized by statistically significantly more severe Internet addiction symptoms measured by KBUI as compared to their non-drinking peers.

Conclusions:

1. Adolescents who consume alcohol, both urban and rural residents, are characterised by statistically significantly more severe symptoms of Internet addiction compared to their peers who do not consume alcohol.

2. Adolescents who live in a city and who consume alcohol are significantly more likely to use Internet pornography than their nondrinking peers.

3. Adolescents who live in urban areas are significantly more likely to use Internet pornography, play violent computer games and search for acceptance and understanding only in online interactions as compared to adolescents who do not consume alcohol.

4. Underage city-dwellers who consume alcohol are significantly more likely to use electronic mail, instant messaging and web pages compared to their rural peers.
\end{abstract}

Keywords: Internet addiction, alcohol, adolescents

\section{Streszczenie}

Celem pracy było określenie podobieństw i różnic między młodzieżą w wieku 13-17 lat, spożywającą i niespożywającą alkoholu mieszkającą w mieście i na wsi w zakresie nasilenia objawów uzależnienia od Internetu.

Grupa badana i metody: Grupę badaną stanowiło 1191 osób (890 dziewcząt i 301 chłopców), w wieku od 13 do 17 roku życia. W pracy zastosowano następujące metody badawcze: Ankietę socjodemograficzną własnej konstrukcji, Ankietę do badania uzależnienia od Internetu w opracowaniu Potembskiej, Kwestionariusz do Badania Uzależnienia od Internetu (KBUI), autorstwa Pawłowskiej i Potembskiej.

Wyniki: Stwierdzono istotne statycznie różnice w zakresie nasilenia objawów uzależnienia od Internetu u młodzieży spożywającej i niespożywającej alkoholu. Wnioski:

1. Młodzież spożywającą alkohol, mieszkającą zarówno w mieście, jak i na wsi charakteryzuje istotnie statystycznie większe nasilenie objawów uzależnienia od Internetu, niż młodzież niespożywającą alkoholu.

2. Młodzież mieszkająca w mieście spożywająca alkohol istotnie częściej niż młodzież niespożywająca alkoholu korzysta z pornografii internetowej.

(C) 2017 Medical University of Lublin. This is an open access article distributed under the Creative Commons Attribution-NonComercial-No Derivs licence (http://creativecommons.org/licenses/by-nc-nd/3.0/) 
3. Młodzież mieszkająca na wsi spożywająca alkohol istotnie częściej niż młodzież niespożywająca alkoholu korzysta z pornografii internetowej, gra w gry komputerowe, w których dominuje przemoc oraz poszukuje jedynie w kontaktach nawiązywanych przez Internet akceptacji i zrozumienia.

4. Nieletni spożywający alkohol mieszkający w mieście znacząco częściej niż mieszkający na wsi korzystają z poczty elektronicznej, komunikatorów internetowych oraz stron WWW.

Słowa kluczowe: uzależnienie od Internetu, alkohol, młodzież

\section{Introduction}

Alcohol is most common psychoactive substance used by adolescents. The problem of alcohol consumption by Polish adolescents was assessed in the year 2011 in the European School Survey Project on Alcohol and Other Drugs (ESPAD) conducted by National Bureau for Drug Prevention and the State Agency for the Prevention of Alcohol-Related Problems (PARPA) and involved the total of 5316 third year junior high school students (aged 15-16 years) and second high school year students (aged 17-18 years). The data obtained in the ESPAD survey [1] show that at alcohol was consumed on at least one occasion by $87.3 \%$ of junior high school students and by $95.2 \%$ of high school students.

Mazur et al. [2] report that alcohol consumption and getting drunk by underage people is accompanied by other risky behaviours. Other researchers [3-9], among risky behaviours in adolescents, coexisting with the use of psychoactive substances, name Internet addiction and the risk of Internet addiction, computer games and use Internet pornography.

The research conducted by Pawłowska et al. [10] involving a group consisting of 1860 people aged 13-19 years living in Lublin Province demonstrated that the Internet addiction criteria are fulfilled by $0.45 \%$ of adolescents living in urban areas and $2.9 \%$ of those living in rural areas, whereas $35.55 \%$ of students living in the city and $30.18 \%$ of students living in rural areas showed a risk of developing this addiction. These researches [11] also found that the adolescents living both in the urban and rural areas using drugs showed significantly more intensified symptoms of Internet addiction, significantly more often played violent online games and used Internet pornography as compared to the adolescents not using drugs.

The authors who study the so called technology addictions $[3,4,5,6]$ draw attention to the relationship between pathological use of the Internet by adolescents and alcohol consumption. According to Potembska and Pawłowska $[12,13]$ alcohol consumption by junior high school students co-exists with the extended time of Internet use and conviction that life without the Internet would be empty, boring and charmless.

Yen et al. [5] pointed out that alcohol is abused by more adolescents addicted to the Internet $(13 \%)$ as compared to the individuals not addicted to the net (5.7\%). Pawłowska et al. [14] indicate that the adolescents who are at risk of developing Internet addiction more often consume alcohol in a stressful situation as compared to the people who are not at risk of this addiction. Some researchers $[7,8,9]$ point out that alcohol consumption is accompanied by Internet pornography use and playing computer games by adolescents. Similarly, Svedin et al. [15] indicate that young men looking at pornography consume alcohol more often as compared to those who do use pornography. In the opinion of Padilla-Walker et al. [8] playing violent computer games is connected with alcohol consumption by adolescents. According to Ream et al. [9] $43 \%$ of adolescents consume alcohol while playing computer games. Mart et al. [16] and Moreno et al. [7] point out that the adolescents using social networking websites are exposed to the contents encouraging to alcohol consumption.

There is a scarcity of research regarding the relationship between the use of psychoactive substances and the Internet addiction, playing violent online games and use of Internet pornography by adolescents. Adopting preventive measures that could hamper the growing number of the above risky behaviours in adolescents requires research in order to know the specific character and prevalence of these phenomena taking into account the place of residence of the respondents.

The aim of the study was to determine the differences and similarities between the adolescents who consume alcohol and those who do not consume it living the urban and rural areas as regards the intensity of Internet addiction symptoms as well as the assessment of alcohol consumption prevalence by underage individuals aged 13-17 years.

\section{Examined group and methods}

Prior to conducting the research the consent was obtained from the Bioethics Committee at the Medical University of Lublin (number KE-0254/94/2012). The research was conducted in 2012 and it involved students attending junior high schools and high schools located in the city of Lublin after obtaining the approval from their principals. The Students completed questionnaires voluntarily and were informed about the anonymity of the results as well as of their scientific character. The examined group comprised 1191 respondents (890 girls and 301 boys) aged 13 - 17 years. Out of the examined group 94 respondents attended junior high schools and 1097- high schools. 
515 students lived in Lublin, whereas 676 students inhabited rural areas in Lublin area. The total of 715 people (441 girls and 182 boys consumed alcohol. It should be noted that the girls completed the questionnaires more willingly as compared to the boys, moreover they more often provided fully completed questionnaires.

\section{The following research methods were used in the study:}

Sociodemographic questionnaire based on which the following variables were determined: gender, age, place of residence, education level, parents' education and family structure of the respondents.

Internet Addiction Questionnaire designed by Potembska based on which it was determined: which web pages are used by the respondents, do they establish contacts with unknown people via the Internet, do they browse Internet pornography and how often does it occur, do the respondents play online games and what are these games as well as what kind of personal details do the make available to other Internet users [17].

Internet Addiction Questionnaire [Kwestionariusz do Badania Uzależnienia od Internetu (KBUI)], designed by Pawłowska and Potembska [17] consists of 50 questions. KBUI describes the following dimensions of the Internet addiction: seeking acceptance and understanding in the interactions only via the Internet; playing violent online games; using instant messaging services, web pages, downloading music, films from websites, browsing web pages; visiting online pornography websites, conduction sexual conversations online and downloading films and pornographic pictures from websites [17]. The minimum score is 0 , whereas the maximum score amounts to 200 points. The respondents who obtained 0-49 pints in the general KBUI scale are considered as not being at risk of Internet addiction, the respondents who are at risk of Internet addiction get $50-109$ points, the result 110 to 200 points denotes Internet addiction [20]. The reliability coefficients for individual KBUI scales are as follows: for Acceptance scale Cronbach's $\alpha$ (alpha) $=0.92$; for Games scale Cronbach's $\alpha$ (alpha) $=0.92$; for Utility function scale Cronbach's $\alpha$ (alpha) $=0.84$; for Internet Addiction scale Cronbach's $\alpha$ (alpha) $=0.90$ and for the general KBUI scale Cronbach's $\alpha$ (alpha) $=0.93$ [17].

\section{Results}

Table 1 shows the results of the t-Student test, which was used to compare the results obtained in the KBUI scales by the adolescent inhabitants of urban and rural areas who consume alcohol and those who do not consume it.
Table 1. Comparison of the mean results obtained in the KBUI scales by adolescents living in the urban and rural areas who consume alcohol and those who do not consume it

\begin{tabular}{|l|c|c|c|c|c|}
\hline \multirow{2}{*}{ KBUI scales } & $\begin{array}{c}\text { They do not } \\
\text { consume } \\
\text { alcohol }\end{array}$ & \multicolumn{2}{c|}{$\begin{array}{c}\text { They con- } \\
\text { sume alcohol }\end{array}$} & \multirow{2}{*}{$\mathrm{t}$} \\
\cline { 2 - 5 } & $\mathrm{M}$ & SD & $\mathrm{M}$ & SD & \\
\hline Urban areas \\
\hline Acceptance & 0.49 & 0.65 & 0.52 & 0.62 & -0.47 \\
\hline Games & 0.49 & 0.79 & 0.63 & 0.89 & -1.89 \\
\hline Computer addiction & 2.12 & 0.73 & 2.32 & 0.65 & $-3.34^{* * *}$ \\
\hline Internet addiction & 0.58 & 0.56 & 0.80 & 0.68 & $-4.10^{* * *}$ \\
\hline Pornography & 0.15 & 0.35 & 0.29 & 0.51 & $-3.95^{* * *}$ \\
\hline KBUI overall result & 35.25 & 21.04 & 42.55 & 23.03 & $-3.82^{* * *}$ \\
\hline \multicolumn{7}{|c|}{ Rural areas } \\
\hline Acceptance & 0.44 & 0.49 & 0.57 & 0.59 & $-3.36^{* * *}$ \\
\hline Games & 0.39 & 0.67 & 0.67 & 0.91 & $-4.69^{* * *}$ \\
\hline Computer addiction & 1.96 & 0.74 & 2.18 & 0.69 & $-4.13^{* * *}$ \\
\hline Internet addiction & 0.53 & 0.57 & 0.73 & 0.66 & $-4.32^{* * *}$ \\
\hline Pornography & 0.11 & 0.31 & 0.33 & 0.58 & $-6.47^{* * *}$ \\
\hline KBUI overall result & 31.45 & 18.82 & 41.93 & 24.08 & $-6.55^{* * *}$ \\
\hline
\end{tabular}

${ }^{*} \mathrm{p}<0.05 ;{ }^{* *} \mathrm{p}<0.01 ;{ }^{* * *} \mathrm{p}<0.01$

The adolescents living in the urban areas who consume alcohol obtained significantly statistically higher results as compared to the students who do not consume alcohol in the KBUI scales: general KBUI scale, Computer addiction, Internet addiction and Pornography. These results mean that adolescents living in the urban areas who consume alcohol significantly more often as compared to their peers who do not drink: use instant messaging, download films and music files from the Internet, extend the time of Internet use, cut down on meals and sleep to remain online, they inform about problems at school, neglect studies and duties due to the amount of the time spent online, they tell lies to their families as regards the amount of time spent online, they use Internet pornography (they watch erotic films), visit Internet forums and chat rooms dedicated to erotic subjects, they inform that they visit pornography websites due to an easy and cheap access to them (Table 1).

The adolescents living in the rural areas who consume alcohol obtained statistically significantly higher results as compared to the students who do not consume alcohol in the KBUI scales: general scale and in the following scales: Acceptance, Games, Internet addiction, Computer addiction and Pornography. These results mean that, as compared to the adolescents who do not consume alcohol, the adolescents living in the rural areas and consuming alcohol, show significantly more intensified Internet addiction symptoms measured in the KBUI scales, manifested by: extended time staying online, preoccupation with the internet use, cutting down on sleep due to the time spent online, reacting with anger or fear when it is impossible to stay online, neglecting studies and other duties in connection with 
the time spent online, preferring online interactions instead of "face to face" encounters. The adolescents living in the rural areas and who consume alcohol significantly more often as compared to their peers who do not consume alcohol, use email, download films and music files from the Internet, express the opinion that only the Internet interlocutors can appreciate, understand, "one can encounter more interesting people online than in reality" (Table 1).

The adolescents living in rural areas and who consume alcohol significantly more often as compared to their peers who do not consume alcohol, play violent computer games because at that time "they are not afraid of anything", they can "express anger without any limitations", "they consider themselves most important", they declare that they like computer games where they "kill enemies", they can "chose the type of weapons and they can "chose the method of killing", while playing games they "consider themselves "the lords of life and death" and experience the sense of power. The adolescents who consume alcohol and live in the rural areas significantly more often, as compared to their peers who do not consume alcohol, use online pornography, engage in erotic conversations, download pornographic films and pictures from the Internet, visit erotic chat rooms and forums, think that online pornography allows them to change a partner without any problem, gives them a sense of safety, they do not have to be afraid that will not come up to the expectations of the other people and inform that they visit pornographic websites because the access to them is easy and cheap (Table 1).

The table below presents the results of the t-Student test which was used to compare the results obtained in the KBUI scales by the girls living in the urban and rural areas (Table 2) who consume alcohol and those who do not consume it.

Table 2. Comparison of mean results obtained in the KBUI scales by underage girls living in the urban and rural areas who consume alcohol and those who do not consume it

\begin{tabular}{|l|c|c|c|c|l|}
\hline \multirow{2}{*}{ KBUI scales } & $\begin{array}{c}\text { They do not } \\
\text { consume } \\
\text { alcohol }\end{array}$ & \multicolumn{2}{c|}{$\begin{array}{c}\text { They con- } \\
\text { sume alcohol }\end{array}$} & \multirow{2}{*}{$\mathrm{t}$} \\
\cline { 2 - 5 } & $\mathrm{M}$ & SD & $\mathrm{M}$ & $\mathrm{SD}$ & \\
\hline \multicolumn{7}{|c|}{ Urban areas } \\
\hline Acceptance & 0.52 & 0.66 & 0.49 & 0.59 & 0.52 \\
\hline Games & 0.34 & 0.67 & 0.37 & 0.71 & -0.42 \\
\hline Computer addiction & 2.16 & 0.70 & 2.36 & 0.62 & $-2.95^{* *}$ \\
\hline Internet addiction & 0.61 & 0.57 & 0.78 & 0.67 & $-2.72^{* *}$ \\
\hline Pornography & 0.12 & 0.31 & 0.16 & 0.38 & -1.14 \\
\hline KBUI overall result & 34.33 & 20.42 & 38.36 & 20.62 & -1.92 \\
\hline \multicolumn{7}{|c|}{ Rural areas } \\
\hline Acceptance & 0.44 & 0.51 & 0.55 & 0.56 & $-2.25^{*}$ \\
\hline Games & 0.23 & 0.44 & 0.35 & 0.64 & $-2.48^{* *}$ \\
\hline Computer addiction & 2.03 & 0.69 & 2.21 & 0.70 & $-2.87^{* *}$ \\
\hline Internet addiction & 0.52 & 0.56 & 0.73 & 0.68 & $-3.65^{* * *}$ \\
\hline Pornography & 0.05 & 0.14 & 0.20 & 0.43 & $-4.98^{* * *}$ \\
\hline KBUI overall result & 29.70 & 16.76 & 37.34 & 21.09 & $-4.45^{* * *}$ \\
\hline *p<0.05; **p<0.01; ${ }^{* * *}$ p $<0.01$ & & \\
\hline
\end{tabular}

The girls living in the urban areas who consume alcohol obtained significantly higher results as compared to the girls who do not consume alcohol in the following KBUI scales: Internet addiction and Computer addiction, which means that the girls who consume alcohol significantly more often than the girls who do not consume alcohol extend the time online, react with anger if they cannot use the Internet, cut down on the sleep due to the time spent online, they more often use Internet messaging and browsers, download from music files and films the Internet and inform that they neglect school and other duties because of the time spent online (Table 2).

The girls living in the rural areas who consume alcohol obtained significantly statistically higher results, as compared to the girls who do not consume alcohol, in all KBUI scales. The girls living in the rural areas who consume alcohol, as compared to the girls who do not consume alcohol, show intensified Internet addiction symptoms, they significantly more often play violent online games, they use Internet pornography, they more often use Internet messaging services, email, they download films and music files and express an opinion that they it is only from the Internet interlocutors that they can get acceptance and understanding (Table 2).

Table 3 presents the results of the t-Student test used to compare the boys living in the urban and rural areas in the KBUI scales.

Table 3. Comparison of mean results obtained in the KBUI scales by underage boys living in the urban and rural areas who consume alcohol and those who do not consume it

\begin{tabular}{|l|c|c|c|c|l|}
\hline \multirow{2}{*}{ KBUI scales } & $\begin{array}{c}\text { They do not } \\
\text { consume } \\
\text { alcohol }\end{array}$ & $\begin{array}{c}\text { They consume } \\
\text { alcohol }\end{array}$ & \multirow{2}{*}{$\mathrm{t}$} \\
\cline { 2 - 5 } & $\mathrm{M}$ & $\mathrm{SD}$ & $\mathrm{M}$ & $\mathrm{SD}$ & \\
\hline Urban areas \\
\hline Acceptance & 0.40 & 0.60 & 0.59 & 0.62 & -1.65 \\
\hline Games & 1.09 & 0.93 & 1.37 & 0.95 & -1.62 \\
\hline Computer addiction & 2.02 & 0.80 & 2.26 & 0.62 & -1.82 \\
\hline Internet addiction & 0.49 & 0.54 & 0.86 & 0.70 & $-3.22^{* *}$ \\
\hline Pornography & 0.25 & 0.47 & 0.67 & 0.66 & $-4.03^{* * *}$ \\
\hline KBUI overall result & 39.41 & 23.77 & 54.66 & 25.17 & $-3.38^{* * *}$ \\
\hline \multicolumn{7}{|c|}{ Rural areas } \\
\hline Acceptance & 0.47 & 0.48 & 0.61 & 0.60 & -1.62 \\
\hline Games & 1.02 & 0.85 & 1.38 & 0.97 & $-2.42^{*}$ \\
\hline Computer addiction & 1.68 & 0.77 & 2.12 & 0.68 & $-3.84^{* * *}$ \\
\hline Internet addiction & 0.61 & 0.63 & 0.70 & 0.56 & -1.04 \\
\hline Pornography & 0.39 & 0.61 & 0.58 & 0.66 & -1.87 \\
\hline KBUI overall result & 39.52 & 24.37 & 51.18 & 24.32 & $-3.01^{* *}$ \\
\hline
\end{tabular}

${ }^{*} \mathrm{p}<0.05 ;{ }^{* *} \mathrm{p}<0.01 ;{ }^{* * *} \mathrm{p}<0.01$

The boys living in the urban areas who consume alcohol obtained significantly statistically higher results, as compared to the boys who do not consume alcohol, in the following KBUI scales: general scale, Internet addiction 
and Pornography. These results inform that the boys living in the urban areas who consume alcohol significantly more often, as compared to the boys who do not consume alcohol, show intensified Internet addiction symptoms and they more often use online pornography (Table 3).

The boys living in the rural areas who consume alcohol obtained significantly statistically higher results as compared to the boys who do not consume alcohol in the following KBUI scales: general scale, Games and Internet addiction, which means that they significantly more often play violent computer games and they show intensified symptoms of the Internet addiction measured by the KBUI (Table 3).

The final stage of the research involved a comparison of the alcohol-consuming adolescents who live in urban and rural areas as regards the symptoms of intensification of Internet addiction measured by the KBUI. The adolescents consuming alcohol and living in urban areas $(M=2,32 ; S D=0,65)$ obtained significantly higher scores $(t=2,86 ; p=0,004)$ as compared to the respondents living in rural areas $(M=2,18 ; S D=0,69)$ in the KBUI scale - Internet addiction. These results show that, as compared to the teenagers living in urban areas, the adolescents who consume alcohol and live in the city significantly more often use electronic mail, Internet messaging services and web pages.

\section{Summary and discussion of the results}

Based on the research it was found that the adolescents consuming alcohol living both in the urban and rural areas are characterised by statistically significantly greater intensification of the Internet addiction symptoms as compared to their peers who do not consume alcohol. The adolescents living both in the urban and rural areas who consume alcohol significantly more often, as compared to the teenagers who do not consume alcohol, use the Internet messaging services, download films and music files from the Internet, use Internet pornography, visit chat rooms and forums and get involved in erotic conversations. The respondents living in the rural areas who consume alcohol significantly more often as compared to their peers who do not consume alcohol express the opinion that it is only on the Internet that one can get acceptance and understanding and they more often play violent computer games. While comparing the teenagers' online activity it was found that the adolescents who consume alcohol and live in the urban areas significantly more often, as compared to their peers living in the rural areas, use electronic mail, Internet messaging services and browsers. The results presented in the study correspond to the opinion of researchers [2-9,14,16], who point to the coexistence of alcohol consumption by adolescents with a pathological Internet use, Internet pornography, playing violent computer games and excessive use of social network services and Internet browsers.
Referring to the previous research conducted by Pawłowska et al. [11], its results pointing to significantly higher intensity of Internet addiction, more frequent use of online pornography and playing violent online games by adolescents who use drugs as compared to the adolescents who do not use drugs, a hypothesis can be formulated that there is a coexistence of use of various psychoactive substances with risky behaviours regarding the Internet use. It can be assumed that the use of psychoactive substances and Internet misuse by adolescents is reinforced following the feedback principle. At the same time psychiatrists, therapists, psychologists, educators point to the increasing prevalence of alcohol consumption by adolescents and decreasing age of alcohol initiation as well as to the increasing prevalence of the risk of Internet addiction and computer games. Therefore, what is of particular importance are multidimensional preventive measures focussed on preventing both addictions of adolescents from various psychoactive substances as well as the so called behavioural addictions.

Preventive programmes including the so-called behavioural addictions, which as demonstrated by previous studies coexist with underage alcohol consumption [6] and use of other psychoactive substances by adolescents [11] fully correspond to the proposal put forward by Mazur and Małkowska-Szkutnik [18] that risky behaviours should be dealt with in the context of the entire range of potential health problems and social problems.

On the basis of the obtained results the following conclusions were formulated:

\section{Conclusions}

1. The adolescents who consume alcohol, living both in the urban and rural areas, are characterised by a more statistically significant intensification of Internet addiction symptoms as compared to their peers who do not consume alcohol.

2. The adolescents who live in the city and who consume alcohol significantly more often use Internet pornography as compared to their peers who do not consume alcohol.

3. The adolescents who live in urban areas significantly more often use Internet pornography, play violent computer games and search for acceptance and understanding only in online interactions as compared the adolescents who do not consume alcohol.

4. The underage individuals living in the urban areas who consume alcohol significantly more often use electronic mail, instant messaging and web pages as compared to their peers living in rural areas. 


\section{Wstęp}

Alkohol jest najbardziej rozpowszechnioną substancją psychoaktywną stosowaną przez młodzież. Problem spożywania alkoholu przez młodzież polską był oceniany w 2011r. w badaniu ESPAD (The European School Survey Project on Alcohol and Other Drug) przeprowadzonym przez Krajowe Biuro ds. Przeciwdziałania Narkomanii oraz Państwową Agencję Rozwiązywania Problemów Alkoholowych (PARPA) na grupie 5316 uczniów klas III szkół gimnazjalnych (15-16 lat) oraz klas II szkół ponadgimnazjalnych (17-18 lat). Dane uzyskane $\mathrm{z}$ badania ESPAD [1] informują, że alkohol przynajmniej raz w życiu spożywało 87,3\% uczniów gimnazjów oraz 95,2\% uczniów szkół ponagimnazjalnych.

Mazur et al. [2] wykazali, że spożywanie alkoholu i upijanie się przez nieletnich łączy się z występowaniem innych zachowań ryzykownych. Wśród zachowań ryzykowanych u młodzieży, współwystępujących ze stosowaniem środków psychoaktywnych badacze [3,4,5,6,7,8,9] wymieniają między innymi uzależnienie i zagrożenie uzależnieniem od Internetu, gier komputerowych oraz korzystanie z pornografii internetowej.

W badaniach, którymi Pawłowska i wsp. [10] objęli grupę 1860 osób w wieku od 13 do 19 roku życia, mieszkającą w województwie lubelskim wykazano, że kryteria uzależnienia od Internetu spełniało $0.45 \%$ młodzieży mieszkającej w mieście i 2.9\% mieszkającej na wsi. Około $35.55 \%$ adolescentów mieszkających w mieście i 30.18\% mieszkających na wsi spełniało kryteria zagrożenia uzależnieniem od Internetu. Badacze ci [11] jednocześnie stwierdzili, że młodzież mieszkająca zarówno w mieście, jak i na wsi stosująca narkotyki ma istotnie bardziej nasilone objawy zagrożenia uzależnieniem od Internetu, istotnie częściej gra w gry online, w których dominuje przemoc oraz korzysta $\mathrm{z}$ pornografii internetowej niż młodzież niestosująca narkotyków.

Autorzy zajmujący się problematyką tzw. uzależnień technologicznych $[3,4,5,6]$ zwracają uwagę na zależności między patologicznym korzystaniem z Internetu przez młodzież a spożywaniem alkoholu. Zdaniem Potembskiej i Pawłowskiej $[12,13]$ spożywanie alkoholu przez gimnazjalistów współwystępuje z wydłużaniem czasu korzystania z Internetu oraz z poczuciem, że życie bez Internetu byłoby puste, nudne i pozbawione uroku.

Yen i wsp. [5] ujawnili, że alkoholu nadużywa więcej młodzieży uzależnionej od Internetu (13\%) niż osób nieuzależnionych od sieci (5,7\%). Pawłowska i wsp. [14] wskazują, że młodzież zagrożona uzależnieniem od Internetu w sytuacjach stresu częściej, niż osoby niezagrożone tym uzależnieniem spożywa alkohol. Niektórzy badacze $[7,8,9]$ podkreślają, że spożywanie alkoholu towarzyszy korzystaniu z pornografii internetowej i graniu w gry komputerowe przez młodzież. Podobnie Svedin et al. [15] podkreślają, że młodzi mężczyźni przeglądający pornografię - częściej niż nieprzeglądający - konsumują alkohol. Zdaniem Padilla-Walker et al. [8] granie w gry komputerowe, w których dominuje przemoc łączy się ze spożywaniem alkoholu przez młodzież. Według Ream i wsp. [9] $43 \%$ młodzieży spożywa alkohol podczas grania w gry komputerowe. Mart et al. [16] oraz Moreno et al. [7] zwracają uwagę, że młodzież korzystająca z portali społecznościowych narażona jest na treści zachęcające do spożywania alkoholu.

Badań dotyczących zależności między stosowaniem środków psychoaktywnych a uzależnieniem od Internetu, graniem w gry z dominującą przemocą oraz korzystaniem z pornografii internetowej przez młodzież jest bardzo mało. Zastosowanie działań profilaktycznych, które zapobiegałyby nasilaniu się wymienionych zachowań ryzykownych u młodzieży wymaga badań, celem poznania specyfiki i rozpowszechnienia tych zjawisk z uwzględnieniem miejsca zamieszkania badanych.

Celem pracy było określenie podobieństw i różnic między młodzieżą spożywającą i niespożywającą alkoholu mieszkającą w mieście i na wsi w zakresie nasilenia objawów uzależnienia od Internetu.

\section{Grupa badana i metody}

Przed przeprowadzeniem badań uzyskano zgodę Komitetu Bioetycznego Akademii Medycznej w Lublinie (numer KE-0254/94/2012). Badanie zostało przeprowadzone w 2012 r. i objęło uczniów uczęszczających do gimnazjów i liceów w Lublinie po uzyskaniu zgody od dyrektorów tych szkół. Uczniowie wypełniali kwestionariusze dobrowolnie i zostali poinformowani o anonimowości wyników, a także o ich naukowym charakterze. Badana grupa składała się z 1191 respondentów (890 dziewcząt i 301 chłopców) w wieku od 13 do 17 lat. W badanej grupie, 94 uczniów uczęszczało do gimnazjów a 1097 do liceów. 515 uczniów było mieszkańcami lublina, a 676 mieszkało na obszarach wiejskich na Lubelszczyźnie. Alkohol spożywało 715 osób (441 dziewcząt i 182 chłopców). Należy zauważyć, że dziewczęta wypełniały kwestionariusze chętniej niż chłopcy, oraz częściej niż chłopcy oddawały kompletnie wypełnione kwestionariusze.

W badaniu wykorzystano następujące metody badawcze:

ankietę socjodemograficzną, na podstawie której określono następujące zmienne: płeć, wiek, miejsce zamieszkania, poziom wykształcenia, wykształcenie rodziców oraz strukturę rodzin badanych.

Kwestionariusz do Badania Uzależnienia od Internetu (KBUI) opracowany przez Pawłowską i Potembską [17], składający się z 50 pytań. KBUI opisuje następujące wymiary uzależnienia od Internetu: poszukiwanie akceptacji i zrozumienia wyłącznie w kontaktach nawiązywanych za 
pośrednictwem Internetu; granie w agresywne gry komputerowe; korzystanie z komunikatorów internetowych, stron internetowych, ściąganie muzyki, filmów z witryn internetowych, przeglądanie stron internetowych; odwiedzanie stron internetowych związanych $\mathrm{z}$ pornografią, prowadzenie rozmów erotycznych za pośrednictwem Internetu i pobieranie plików z filmami oraz zdjęciami pornograficznymi ze stron internetowych [17]. Minimalny wynik wynosi 0 a maksymalny 200 punktów. Respondentów, którzy uzyskają od 0 do 49 punktów w skali ogólnej KBUI uznaje się za niezagrożonych uzależnieniem od Internetu, respondenci zagrożeni uzależnieniem od Internetu otrzymują od 50 do 109 punktów, a wynik od 110 do 200 punktów oznacza uzależnienie od Internetu [19]. Współczynniki rzetelności dla poszczególnych skal KBUI wynoszą: dla skali Akceptacja, alfa Cronbacha=0,92; dla skali Gry, alfa Cronbacha=0,92; dla skali Funkcja użytkowa, alfa Cronbacha $=0,84$; dla skali- Uzależnienie od Internetu alfa Cronbacha=0,89; dla skali Pornografia, alfa Cronbacha $=0,90$, a dla skali ogólnej KBUI, alfa Cronbacha =0,93.[17].

\section{Wyniki}

W pierwszym etapie analiz porównano testem t-Studenta wyniki uzyskane w zakresie skal KBUI przez młodzież spożywającą i niespożywającą alkoholu mieszkającą w mieście i na wsi (tab.1).

Tab.1. Porównanie średnich wyników uzyskanych w skalach KBUI przez nieletnią młodzież mieszkającą w mieście i na wsi spożywającą i niespożywającą alkoholu

\begin{tabular}{|l|c|c|c|c|c|}
\hline \multirow{6}{*}{ KBUI scales } & $\begin{array}{c}\text { Nie spożywają } \\
\text { alkoholu }\end{array}$ & \multicolumn{2}{c|}{$\begin{array}{c}\text { Spożywają } \\
\text { alkohol }\end{array}$} & \multirow{2}{*}{ t } \\
\cline { 2 - 5 } & M & SD & M & SD & \\
\hline Acceptance & 0,49 & 0,65 & 0,52 & 0,62 & $-0,47$ \\
\hline Games & 0,49 & 0,79 & 0,63 & 0,89 & $-1,89$ \\
\hline Computer addiction & 2,12 & 0,73 & 2,32 & 0,65 & $-3,34^{* * *}$ \\
\hline Internet addiction & 0,58 & 0,56 & 0,80 & 0,68 & $-4,10^{* * *}$ \\
\hline Pornography & 0,15 & 0,35 & 0,29 & 0,51 & $-3,95^{* * *}$ \\
\hline KBUI overall result & 35,25 & 21,04 & 42,55 & 23,03 & $-3,82^{* * *}$ \\
\hline \multicolumn{7}{|c|}{ Rural areas } \\
\hline Acceptance & 0,44 & 0,49 & 0,57 & 0,59 & $-3,36^{* * *}$ \\
\hline Games & 0,39 & 0,67 & 0,67 & 0,91 & $-4,69^{* * *}$ \\
\hline Computer addiction & 1,96 & 0,74 & 2,18 & 0,69 & $-4,13^{* * *}$ \\
\hline Internet addiction & 0,53 & 0,57 & 0,73 & 0,66 & $-4,32^{* * *}$ \\
\hline Pornography & 0,11 & 0,31 & 0,33 & 0,58 & $-6,47^{* * *}$ \\
\hline KBUI overall result & 31,45 & 18,82 & 41,93 & 24,08 & $-6,55^{* * *}$ \\
\hline
\end{tabular}

${ }^{*} \mathrm{p}<0,05 ;{ }^{* *} \mathrm{p}<0,01 ;{ }^{* * *} \mathrm{p}<0,01$

Młodzież mieszkająca w mieście, spożywająca alkohol uzyskała istotnie statystycznie wyższe wyniki od uczniów niespożywających alkoholu w zakresie skal KBUI: skali ogólnej KBUI, Uzależnienie od komputera, Uzależnienie od Internetu oraz Pornografia. Wyniki te oznaczają, że adolescenci mieszkający w mieście, spożywający alkohol znacząco częściej niż niespożywający alkoholu: korzystają z komunikatorów internetowych, ściągają filmy i pliki z muzyką z Internetu, wydłużają czas korzystania z Internetu, rezygnują z posiłków, snu na rzecz korzystania $\mathrm{z}$ sieci, informują o problemach w szkole, zaniedbywaniu nauki i obowiązków w związku z ilością czasu poświęcanego na korzystanie z Internetu, okłamują rodzinę co do czasu spędzanego w Internecie, reagują agresją, gdy nie mogą korzystać z Internetu, korzystają z pornografii internetowej (ogląda filmy erotyczne), odwiedzają fora i czaty o tematyce erotycznej, prowadzą rozmowy o treści erotycznej, informują, że strony pornograficzne odwiedzają z uwagi na łatwy i tani dostęp (tabela1).

Młodzież mieszkająca na wsi, spożywająca alkohol uzyskała istotnie statystycznie wyższe wyniki od uczniów niespożywających alkoholu w zakresie skal KBUI: skali ogólnej, oraz w skalach - Akceptacja, Gry, Uzależnienie od Internetu, Uzależnienie od komputera oraz Pornografia. Wyniki te oznaczają, że młodzież mieszkająca na wsi, spożywająca alkohol ma znacząco bardziej niż młodzież niespożywająca alkoholu, nasilone objawy uzależnienia od Internetu mierzone KBUI, przejawiające się: przedłużaniem czasu korzystania $\mathrm{z}$ sieci, stałym myśleniem o korzystaniu z Internetu, rezygnowaniem ze snu na rzecz czasu spędzanego na korzystaniu z Internetu, reagowaniem złością lub lękiem w sytuacji niemożności skorzystania z sieci, zaniedbywaniem nauki i innych obowiązków w związku z czasem poświęcanym na korzystanie z Internetu, ograniczaniem kontaktów „twarzą w twarz” na rzecz czasu spędzanego w Internecie. Młodzież mieszkająca na wsi, spożywająca alkohol znacząco częściej niż młodzież niespożywająca alkoholu korzysta z poczty internetowej, ściąga filmy i pliki z muzyką z sieci, wyraża przekonanie, że: tylko internetowi rozmówcy potrafią docenić, zrozumieć, „w Internecie można znaleźć bardziej interesujących ludzi, niż w rzeczywistości" (tabela 1).

Młodzież mieszkająca na wsi, spożywająca alkohol znacząco częściej niż młodzież niespożywająca alkoholu gra w gry komputerowe, w których dominuje przemoc, gdyż wtedy: „niczego nie boi się”, może „bez ograniczeń wyrażać złość”, „czuje się najważniejsza”, deklaruje, że lubi gry komputerowe, w których „zabija wrogów”, może „wybrać rodzaj broni i zadawania śmierci”, grając w gry „czuje się władcą życia i śmierci” oraz doświadcza poczucia władzy. Adolescenci spożywający alkohol mieszkający na wsi istotnie częściej od adolescentów niespożywających alkoholu: korzystają z pornografii internetowej, prowadzą rozmowy o treści erotycznej, ściągają filmy i zdjęcia pornograficzne $z$ Internetu, odwiedzają czaty i fora o tematyce erotycznej, uważają, że: pornografia internetowa daje możliwość swobodnej zmiany partnera, poczucie bezpieczeństwa, nie muszą obawiać się, że nie spro- 
stają czyimś wymaganiom oraz informują, że odwiedzają strony pornograficzne z uwagi na łatwy i tani dostęp (tabela 1).

Poniżej zamieszczono wyniki testu t-Studenta, którym porównano rezultaty uzyskane przez dziewczęta $\mathrm{w}$ zakresie skal KBUI mieszkające $\mathrm{w}$ mieście i na wsi (tab.2) spożywające i niespożywające alkoholu.

Tab.2. Porównanie średnich wyników uzyskanych w skalach KBUI przez nieletnie dziewczęta mieszkające w mieście i na wsi spożywające i niespożywające alkoholu

\begin{tabular}{|l|c|c|c|c|c|}
\hline \multirow{7}{*}{\multicolumn{1}{|c|}{ KBUI scales }} & $\begin{array}{c}\text { Nie spożywają } \\
\text { alkoholu }\end{array}$ & \multicolumn{2}{c|}{$\begin{array}{c}\text { Spożywają } \\
\text { alkohol }\end{array}$} & \multirow{2}{*}{$\mathrm{t}$} \\
\cline { 2 - 5 } & $\mathrm{M}$ & SD & $\mathrm{M}$ & $\mathrm{SD}$ & \\
\hline Acceptance & 0,52 & 0,66 & 0,49 & 0,59 & 0,52 \\
\hline Games & 0,34 & 0,67 & 0,37 & 0,71 & $-0,42$ \\
\hline Computer addiction & 2,16 & 0,70 & 2,36 & 0,62 & $-2,95^{* *}$ \\
\hline Internet addiction & 0,61 & 0,57 & 0,78 & 0,67 & $-2,72^{* *}$ \\
\hline Pornography & 0,12 & 0,31 & 0,16 & 0,38 & $-1,14$ \\
\hline KBUI overall result & 34,33 & 20,42 & 38,36 & 20,62 & $-1,92$ \\
\hline \multicolumn{7}{|c|}{ Rural areas } \\
\hline Acceptance & 0,44 & 0,51 & 0,55 & 0,56 & $-2,25^{*}$ \\
\hline Games & 0,23 & 0,44 & 0,35 & 0,64 & $-2,48^{* *}$ \\
\hline Computer addiction & 2,03 & 0,69 & 2,21 & 0,70 & $-2,87^{* *}$ \\
\hline Internet addiction & 0,52 & 0,56 & 0,73 & 0,68 & $-3,65^{* * *}$ \\
\hline Pornography & 0,05 & 0,14 & 0,20 & 0,43 & $-4,98^{* * *}$ \\
\hline KBUI overall result & 29,70 & 16,76 & 37,34 & 21,09 & $-4,45^{* * *}$ \\
\hline
\end{tabular}

${ }^{*} \mathrm{p}<0,05 ;{ }^{* *} \mathrm{p}<0,01 ;{ }^{* * *} \mathrm{p}<0,01$

Dziewczęta mieszkające w mieście spożywające alkohol uzyskały istotnie wyższe wyniki od dziewcząt niespożywających alkoholu w zakresie skal KBUI: Uzależnienie od Internetu i Uzależnienie od komputera, co oznacza, że dziewczęta spożywające alkohol istotnie częściej niż dziewczęta niespożywające alkoholu wydłużają czas korzystania z sieci, reagują złością, gdy nie mogą skorzystać z Internetu, rezygnują ze snu na rzecz czasu spędzanego w sieci, częściej korzystają z komunikatorów i przeglądarek internetowych, ściągają z Internetu na swój komputer pliki z muzyką i filmy oraz informują, że zaniedbują naukę i inne obowiązki z powodu czasu spędzanego w sieci (tabela 2).

Dziewczęta mieszkające na wsi spożywające alkohol uzyskały istotnie statystycznie wyższe wyniki od uczennic niespożywających alkoholu w zakresie wszystkich skal KBUI. Dziewczęta mieszkające na wsi spożywające alkohol mają znacząco bardziej niż dziewczęta niespożywające alkoholu nasilone objawy uzależnienia od Internetu, znacząco częściej grają w gry komputerowe, w których dominuje przemoc, korzystają $\mathrm{z}$ pornografii internetowej, częściej korzystają z komunikatorów internetowych, poczty elektronicznej, ściągają filmy i pliki z muzyką z sieci oraz wyrażają przekonanie, że tylko od internetowych rozmówców mogą otrzymać akceptację i zrozumienie (tabela 2).
W tabeli 3 zamieszczono wyniki testu t-Studenta, którym porównano chłopców mieszkających w mieście i na wsi w zakresie skal KBUI.

Tab.3. Porównanie średnich wyników uzyskanych w skalach KBUI przez nieletnich chłopców mieszkających w mieście i na wsi spożywających i niespożywających alkoholu

\begin{tabular}{|l|c|c|c|c|l|}
\hline \multirow{2}{*}{ KBUI scales } & $\begin{array}{c}\text { Nie spożywają } \\
\text { alkoholu }\end{array}$ & $\begin{array}{c}\text { Spożywają } \\
\text { alkohol }\end{array}$ & \multirow{2}{*}{$\mathrm{t}$} \\
\cline { 2 - 5 } & $\mathrm{M}$ & $\mathrm{SD}$ & $\mathrm{M}$ & $\mathrm{SD}$ & \\
\hline Urban areas \\
\hline Acceptance & 0,40 & 0,60 & 0,59 & 0,62 & $-1,65$ \\
\hline Games & 1,09 & 0,93 & 1,37 & 0,95 & $-1,62$ \\
\hline Computer addiction & 2,02 & 0,80 & 2,26 & 0,62 & $-1,82$ \\
\hline Internet addiction & 0,49 & 0,54 & 0,86 & 0,70 & $-3,22^{* *}$ \\
\hline Pornography & 0,25 & 0,47 & 0,67 & 0,66 & $-4,03^{* * *}$ \\
\hline KBUI overall result & 39,41 & 23,77 & 54,66 & 25,17 & $-3,38^{* * *}$ \\
\hline \multicolumn{7}{|c|}{ Rural areas } \\
\hline Acceptance & 0,47 & 0,48 & 0,61 & 0,60 & $-1,62$ \\
\hline Games & 1,02 & 0,85 & 1,38 & 0,97 & $-2,42^{*}$ \\
\hline Computer addiction & 1,68 & 0,77 & 2,12 & 0,68 & $-3,84^{* * *}$ \\
\hline Internet addiction & 0,61 & 0,63 & 0,70 & 0,56 & $-1,04$ \\
\hline Pornography & 0,39 & 0,61 & 0,58 & 0,66 & $-1,87$ \\
\hline KBUI overall result & 39,52 & 24,37 & 51,18 & 24,32 & $-3,01^{* *}$ \\
\hline
\end{tabular}

${ }^{*} \mathrm{p}<0,05 ;{ }^{* *} \mathrm{p}<0,01 ;{ }^{* * *} \mathrm{p}<0,01$

Chłopcy mieszkający w mieście spożywający alkohol uzyskali istotnie statystycznie wyższe wyniki od chłopców niespożywających alkoholu w skalach KBUI: skali ogólnej, Uzależnienie od Internetu oraz Pornografia. Wyniki te informują, że chłopcy mieszkający w mieście spożywający alkohol istotnie częściej niż chłopcy niespożywający alkoholu mają nasilone objawy uzależnienia od Internetu oraz częściej korzystają z pornografii internetowej (tabela 3).

Chłopcy mieszkający na wsi, spożywający alkohol uzyskali istotnie statystycznie wyższe wyniki od chłopców niespożywających alkoholu w skalach KBUI: skali ogólnej, Gry oraz Uzależnienie od komputera, co oznacza, że znacząco częściej: grają w gry komputerowe, w których dominuje przemoc oraz mają bardziej nasilone objawy uzależnienia od Internetu mierzone KBUI (tabela 3).

W końcowym etapie badań porównano młodzież spożywającą alkohol mieszkającą na wsi i w mieście w zakresie nasilenia objawów uzależnienia od Internetu mierzonego KBUI. Młodzież spożywająca alkohol, zamieszkała $\mathrm{w}$ mieście $(\mathrm{M}=2,32 ; \mathrm{SD}=0,65)$ uzyskała istotnie wyższe wyniki $(\mathrm{t}=2,86 ; \mathrm{p}=0,004)$ od badanych mieszkających na wsi $(M=2,18 ; \mathrm{SD}=0,69)$ w skali KBUI Uzależnienie od komputera. Wyniki te informują o tym, że młodzież spożywająca alkohol mieszkająca w mieście istotnie częściej niż młodzież mieszkająca na wsi korzysta z poczty elektronicznej, komunikatorów internetowych oraz stron WWW. 


\section{Podsumowanie i dyskusja wyników}

Na podstawie wyników badań stwierdzono, że młodzież spożywającą alkohol, mieszkającą zarówno w mieście, jak i na wsi charakteryzuje istotnie statystycznie większe nasilenie objawów uzależnienia od Internetu, niż młodzież niespożywającą alkoholu. Adolescenci mieszkający zarówno w mieście, jak i na wsi spożywający alkohol znacząco częściej niż młodzież niespożywająca alkoholu: korzystają z komunikatorów internetowych, ściągają filmy i pliki z muzyką z Internetu, korzystają z pornografii internetowej, odwiedzają fora i czaty o tematyce erotycznej oraz prowadzą rozmowy o treści erotycznej. Badani mieszkający na wsi, spożywający alkohol znacząco częściej niż młodzież niespożywająca alkoholu wyrażają przekonanie, że tylko w Internecie można zdobyć akceptację i zrozumienie oraz częściej grają w gry komputerowe, w których dominuje przemoc. Porównując aktywność wykazywaną w Internecie przez nieletnich stwierdzono, że młodzież spożywająca alkohol mieszkająca w mieście istotnie częściej niż mieszkająca na wsi korzysta z poczty elektronicznej, komunikatorów i przeglądarek internetowych. Przedstawione w pracy wyniki są spójne z opinią badaczy [2-9,14,16], którzy wskazują na współwystępowanie spożywania alkoholu przez młodzież z patologicznym korzystaniem z Internetu, pornografii internetowej, graniem w gry komputerowe, w których dominuje przemoc oraz nadmiernym korzystaniem z portali społecznościowych i przeglądarek internetowych.

Nawiązując do wcześniejszych badań przeprowadzonych przez Pawłowską i wsp. [11], których wyniki wskazują na istotnie większe nasilenie objawów uzależnienia od Internetu, częstsze korzystanie z pornografii internetowej i grania w gry online z dominującą przemocą przez młodzież stosującą narkotyki niż przez grupę młodzieży niestosującej narkotyków, można sformułować hipotezę mówiącą o współwystępowaniu stosowania różnych środków psychoaktywnych $\mathrm{z}$ zachowaniami ryzykownymi dotyczącymi korzystania z Internetu. Można przypuszczać, że stosowanie środków psychoaktywnych i nieprawidłowe korzystanie z Internetu przez młodzież ulega wzmocnieniu na zasadzie sprzężenia zwrotnego. Jednocześnie psychiatrzy, terapeuci, psycholodzy, pedagodzy zwracają uwagę na wzrost rozpowszechnienia spożywania alkoholu przez młodzież oraz obniżanie się wieku inicjacji alkoholowej, a także wzrost rozpowszechnienia zagrożenia uzależnieniem od Internetu i gier komputerowych. Dlatego też bardzo ważne są wielokierunkowe oddziaływania profilaktyczne, mające na celu zapobieganie zarówno uzależnieniu u młodzieży od różnych środków psychoaktywnych, jak i uzależnieniom tzw. behawioralnym.

Programy profilaktyczne uwzględniające tzw. uzależnienia behawioralne, które, jak wskazują badania współwystępują ze spożywaniem alkoholu przez nieletnich [6] i stosowaniem przez młodzież innych środków psychoaktywnych [11] wpisują się w pełni w zgłaszany przez Mazur i Małkowską-Szkutnik [18] postulat rozpatrywania zachowań ryzykownych $\mathrm{z}$ punktu widzenia całego kompleksu potencjalnych problemów zdrowotnych i społecznych.

Na podstawie uzyskanych wyników sformułowano następujące wnioski:

\section{Wnioski}

1. Młodzież spożywającą alkohol, mieszkającą zarówno w mieście, jak i na wsi charakteryzuje istotnie statystycznie większe nasilenie objawów uzależnienia od Internetu, niż młodzież niespożywającą alkoholu.

2. Młodzież mieszkająca w mieście spożywająca alkohol istotnie częściej niż młodzież niespożywająca alkoholu korzysta z pornografii internetowej.

3. Młodzież mieszkająca na wsi spożywająca alkohol istotnie częściej niż młodzież niespożywająca alkoholu korzysta z pornografii internetowej, gra w gry komputerowe, w których dominuje przemoc oraz poszukuje jedynie w kontaktach nawiązywanych przez Internet akceptacji i zrozumienia.

4. Nieletni spożywający alkohol mieszkający w mieście znacząco częściej niż mieszkający na wsi korzystają z poczty elektronicznej, komunikatorów internetowych oraz stron WWW.

\section{Conflict of interest}

The authors have declared no conflict of interest.

\section{Acknowledgments}

This paper was financed under the Medical University in Lublin's grants DS 191 and MNmb 636.

\section{References:}

1. ESPAD. Europejski program badań ankietowych w szkołach. Używanie alkoholu i narkotyków przez młodzież szkolną. Raport z ogólnopolskich badań ankietowych zrealizowanych w 2011r. Instytut Psychiatrii i Neurologii, 2011.

2. Mazur J, Kowalewska A, Woynarowska B. Alcohol drinking and other risk behaviors among adolescents aged 11-15 years. Med Wieku Rozwoj. 2003; 7(1 Pt 2): 75-89.

3. Yen JY, Ko CH, Yen CF, Chen SH, Chung WL, Chen CC. Psychiatric symptoms in adolescents with Internet addiction: Comparison with substance use. Psychiatry Clin Neurosci. 2008; 62(1): 9-16.

4. Lam LT, Peng ZW, Mai JC, Jing J. Factors associated with Internet addiction among adolescents. Cyberpsychol Behav. 2009; 12(5): 551-555.

5. Yen JY, Ko CH, Yen CF, Chen CS, Chen CC. The association between harmful alcohol use and Internet addiction among college stu- 
dents: comparison of personality. Psychiatry Clin Neurosci. 2009; 63(2): 218-224.

6. Potembska E. Uzależnienie i zagrożenie uzależnieniem od Internetu u młodzieży. Niepublikowana rozprawa doktorska. Uniwersytet Medyczny w Lublinie. Lublin, 2011.

7. Moreno MA, Briner LR, Williams A, Walker L, Christakis DA. Real use or "real cool": Adolescents speak out about displayed alcohol references on social networking websites. J Adolesc Health. 2009; 45(4): 420-422.

8. Padilla-Walker LM, Nelson LJ, Carrol JS, Jensen AC. More Than a Just Game: Video Game and Internet Use During Adulthood. J Youth Adolesc. 2010; 39(2): 103-113.

9. Ream GL, Elliot LC, Dunlap E. Patterns of and Motivations for Concurrent Use of Video Games and Substances. Int J Environ Res Public Health 2011; 8(10): 3999-4012.

10. Pawłowska B, Zygo M, Potembska E, Kapka-Skrzypczak L, Dreher P, Kędzierski Z. Prevalence of Internet addiction and the risk of developing it as exemplified by a group of Polish adolescents from urban and rural areas. Ann Agric Environ Med. 2015; 22(1): 129-136.

11. Pawłowska B, Zygo M, Potembska E, Kapka-Skrzypczak L, Dreher $P$, Kędzierski Z. Psychoactive substances use experience and addiction or risk of addiction among by Polish adolescents living in rural and urban areas. Ann Agric Environ Med. 2014; 21(4): 776782.

12. Potembska E, Dworzański W, Pawłowska B. Spożywanie alkoholu a uzależnienie od Internetu u młodzieży gimnazjalnej. Bad Schizofr. 2009; 10(10): 330-333.

13. Potembska E, Pawłowska B. Zależności między uzależnieniem od Internetu a spożywaniem alkoholu i stosowaniem środków psychoaktywnych u uczniów gimnazjum i liceum. Psychiatr Pol. 2010; 44(3, Suppl. 1): 195.
14. Pawłowska B, Potembska E, Dworzański W. Internet addiction and coping with stress in secondary school students. In: Janowski K, Steuden S (eds.). Biopsychosocial Aspects of Health and Disease. Lublin, CPPP Scientific Press, 2009 v. 2, p. 71-78.

15. Svedin CG, Åkerman I, Priebe G. Frequent users of pornography. A population based epidemiological study of Swedish male adolescents. J Adolesc. 2011; 34(4): 779-788.

16. Mart M, Mergendoller J, Simon M. Alcohol promotion on Facebook. J Global Drug Policy Pract. 2009; 3 (3): 1-8.

17. Pawłowska B, Potembska E. Właściwości psychometryczne Kwestionariusza do Badania Uzależnienia od Internetu (KBUI). Bad Schizofr. 2009; 10(10): 310-321.

18. Raport HBSC 2010. Zachowania zdrowotne młodzieży szkolnej. J. Mazur i A. Małkowska-Szkutnik (eds). Warszawa: Instytut Matki i Dziecka 2011.

\section{Correspondence address}

Beata Pawłowska,

2nd Department of Psychiatry and Psychiatric Rehabilitation, Medical University in Lublin,

ul. Głuska 1, 20-439 Lublin, Poland

E-mail: pawlowskabeata@tlen.pl

Otrzymano: 24.04 .2017

Zrecenzowano: 10.05.2017, 14.05.2017

Przyjęto do druku: 22.05.2017 